\title{
Homiletical perspectives on preaching the truth to post-pandemic postmodernist listeners with reference to the emotional appeal of the text
}

\begin{tabular}{|c|c|}
\hline \multicolumn{2}{|c|}{$\begin{array}{l}\text { Authors: } \\
\text { Ferdi P. Kruger } 1 \text { (1) } \\
\text { Ben J. de Klerk }{ }^{1}\end{array}$} \\
\hline \multicolumn{2}{|c|}{$\begin{array}{l}\text { Affiliations: } \\
{ }^{1} \text { Unit for Reformational } \\
\text { Theology and the } \\
\text { Development of the South } \\
\text { African Society, Faculty of } \\
\text { Theology, North-West } \\
\text { University, Potchefstroom, } \\
\text { South Africa }\end{array}$} \\
\hline \multicolumn{2}{|c|}{$\begin{array}{l}\text { Corresponding author: } \\
\text { Ferdi Kruger, } \\
\text { ferdi.kruger@nwu.ac.za }\end{array}$} \\
\hline \multicolumn{2}{|c|}{$\begin{array}{l}\text { Dates: } \\
\text { Received: } 25 \text { Feb. } 2021 \\
\text { Accepted: } 03 \text { May } 2021 \\
\text { Published: } 23 \text { June } 2021\end{array}$} \\
\hline \multicolumn{2}{|c|}{$\begin{array}{l}\text { How to cite this article: } \\
\text { Kruger, F.P. \& De Klerk, B.J., } \\
\text { 2021, 'Homiletical } \\
\text { perspectives on preaching } \\
\text { the truth to post-pandemic } \\
\text { postmodernist listeners with } \\
\text { reference to the emotional } \\
\text { appeal of the text', In } \\
\text { die Skriflig 55(1), a2737. } \\
\text { https://doi.org/10.4102/ids. } \\
\text { v55i1.2737 }\end{array}$} \\
\hline \multicolumn{2}{|c|}{$\begin{array}{l}\text { Copyright: } \\
\text { (c) 2021. The Authors. } \\
\text { Licensee: AOSIS. This work } \\
\text { is licensed under the } \\
\text { Creative Commons } \\
\text { Attribution License. }\end{array}$} \\
\hline \multicolumn{2}{|l|}{ Read online: } \\
\hline 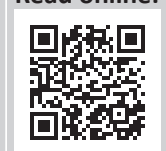 & $\begin{array}{l}\text { Scan this QR } \\
\text { code with your } \\
\text { smart phone or } \\
\text { mobile device } \\
\text { to read online. }\end{array}$ \\
\hline
\end{tabular}

When it comes to debating the background of this article, the matter of preaching to people in a post-pandemic postmodernist world is standing central. One should always acknowledge that listeners do not listen with their ears only. In their quest of listening to sermons, people are looking for meaningfulness. In the act of listening, listeners' senses are optimally utilised because, in the active listening process, they start to listen along with seeing and feeling, as they are being introduced to the feelings or emotions that emanate from a particular message. It is the authors' objective to pay attention to listeners that are seeking to embrace the truth. Therefore, the sacramental essence of transform people's lives, and for them to look in the right direction for answers in their search, and that cannot be underestimated. This article delineates the idea that preaching the gospel amounts to more than a mere stirring up of emotions. In fact, in a post-pandemic postmodernist world where listeners yearn for answers amid afflictions, profound preaching requires a renewed interest in the feelings emanating from the text itself. Our research question phrases the matter as follows: Does preaching to post-pandemic postmodernist people centre on an emotional tone of speaking, or does it, instead, centre on the feelings evoked by the text itself? This question is addressed by adhering to Dingemans' visualisation of a research project that reckons with descriptive, normative and strategic perspectives. We, as the authors, aim to indicate the result of this investigation in the following manner: Although emotional manipulation may be a pitfall, one cannot ignore that persuasive preaching is intentional and aims to move listeners to find delight in the emotional appeal made by the passage in the gospel. Viewed from a Reformational viewpoint, this research could better illuminate the challenges preachers face in communicating to listeners in a postmodern post-pandemic world.

Contribution: This article contributes by offering homiletical perspectives to two waves that have an interplay, namely postmodernism and reality within a post-pandemic world. Preaching the gospel that deals with the feelings in the text could provide an impetus to this kind of praxis.

Keywords: preaching; postmodernity; remembrance; feelings; emotions; text.

\section{Introduction}

Alvin Toffler's book, The future shock (1980), remains influential. In this book, Toffler (1980:23) is alerting people that the danger of experiencing too much too soon has the potential to confront people with an information overload. Toffler's views of how rapid changes will influence people's sense of the world within the traditional structures of their families, churches and workplaces where the notion of permanence was previously seen as untouchable were communicated nearly 50 years ago. The COVID-19 pandemic is a powerful reminder for people that could experience too many events too soon. In homiletical research, attention was given to the challenging essence of preaching in places where a post modernistic view prevails. We, as the authors, now embark on this idea that a postmodernist outlook should also be seen as an endeavour to make sense of the world. Amid this reflection, a serious challenge has emerged in 2020 in the form of the COVID-19 pandemic. We want to indicate that scholars are already speaking of a post-pandemic postmodernist reality that should be addressed (Gilder 2020:7). The intention is to suggest that preaching to listeners in this challenging time is not something that requires a new fashion of preaching, but rather to reflect on the importance of preaching the emotional appeal of the passage from the gospel.

The interplay between preachers' honorary task to deliver sermons (cf. scholars' current emphasis on preaching as a performance act) and listeners' pressing responsibility to participate 
in listening and doing is intriguing (Reid 2010:7). This interplay is multifaceted. Christians believe that God is speaking in every sermon delivered to them and that all listeners should indeed hear this voice for the message to become internalised with a view to daily life. Consequently, theologians often discuss the urge of finding delight in the privilege to preach the truth of the gospel while struggling with listeners' receptiveness to their preaching (Ramey 2010:10). The following examples could briefly be mentioned: As voiced by Augustine, the rhetorical triad of Aristotle, namely preaching that should instruct, motivate and move, embodies a classical attempt to emphasise the role of preachers in guiding listeners towards willingness to appropriate sermons (Yang 2007:27). In the rhetorical understanding, the persuasive dimension of sermons was also related to this classical trio (De Leede \& Stark 2016:121). The function of logos, ethos and pathos within sermons has consequently received thorough attention. More recently, Troeger (2012:79) has introduced the idea of imaginative preaching that should enable listeners to picture God in a fragmented world.

Mueller (2006:65), for example, defines the challenge of preaching to contemporary listeners by highlighting that the Zeitgeist of postmodernity could be seen as a worldview without a centre. Within a single local church, certain people, for example, struggle to understand the new world of postmodernity, while others still struggle to understand the thought patterns of yesterday's world (Rabey 2001:62). The unique challenge becomes evident. While preachers are still struggling with a homiletical praxis to connect with listeners, a new wave of living in a post-pandemic world has emerged. The Zeitgeist of a post-pandemic postmodernist outlook needs a homiletical praxis that could enable listeners to receive insight into the challenges of daily life.

We offer the results of our research about the kind of praxis needed within a changing environment where suspicion of and sensitivity to fixed expressions exist. In postmodernism, 'truth' is established constructively and not discovered (Groothuis 2004:441). Therefore, it is unavoidable that language used in sermons endeavours to communicate the metanarrative of the kingdom of God unambiguously, or simply by formulating truths in ostensibly closed and dogmatic terms, is often a challenge (Pieterse 2005:410). The pitfalls of a praxis where sermons act as a mere dumpingsite of knowledge or functions as a unilateral attempt to generate emotions without compelling to the gospel should be avoided. In fact, profound preaching to listeners yearning for answers amid afflictions in a postmodern world prompts renewed interest in the feelings contained in the meaning of the text itself. The question for this research could be formulated in the following manner: Does preaching to listeners in a post-pandemic postmodernist world centre on an emotional tone of speaking, evoking emotions, or does it, instead, centre on the feelings evoked by the text itself?
This article is the first of two articles related to a homiletical praxis interested in what listeners are experiencing. In this article, we intend to offer research that deals with the opportunity to utilise the dynamics of the gospel to communicate to listeners with a post-pandemic postmodernist outlook on life, while the second article will offer perspectives on what should be communicated to listeners in order to experience meaningfulness in their lives. The visualisation by Dingemans (1991:33) of employing a practical theological methodology to examine this matter has been adopted. This approach includes acknowledgement of the hermeneutical interaction between the various phases of research to provide room for interplay between the analytical description of the praxis and listeners' values, and views on preaching over the years. It has the following three legs:

- A descriptive-analytical perspective on the practical theological situation;

- Normative perspectives; and

- Strategies for changing a problematic praxis.

A qualitative literature study will be utilised to provide perspectives on the matter under examination, that is, Dingemans's visualisation of practical theological research. After the present piece, strategic perspectives will be given on how preaching to post-pandemic postmodernist people is central to the feelings of a text.

\section{Descriptive-analytical account of the theological situation Delineation of terminology related to preaching
truth to post-everything people}

The following aspects will be examined to describe terminology related to a problematic praxis to be employed here.

\section{Descriptive-analytical perspectives on post-truth or truth?}

Scientists call the world we live in a world of post-truth where strands of reality are woven into truth as we would wish to see it in support of our own interests. The Oxford Dictionary (2016) chose the word post-truth as their international word of the year. Defined as an adjective relating to or denoting circumstances in which objective facts are less influential in shaping public opinion than appeals to emotion and personal belief, the editors said that use of the term post-truth had increased with approximately $2000 \%$ in 2016, compared with the previous year (Jameson 2018:184). Naugle (2002) makes this important observation:

In the postmodern period confidence in humanity as an objective, omnicompetent knower has been smashed, destroying any hopes of ascertaining the truth about the universe, its facts or its values. (p. 174)

Those who cling to a concept of objective truth are viewed as creatures from another planet. Forke (2016:155) avers that we are clearly in the second phase of the postmodern revolution. This is a period when the desire to maintain a 
concept of truth is seen as a weakness. This dependence on 'truth' is viewed as a moral failure characterised by the need to subject others to a dominant personal truth.

Canale (2007:99) has demonstrated that postmodern 'hermeneutical reason' replaces the 'epistemological foundationalism' of classical and modern times. This epistemological shift implies that truth is fluid over time. We can no longer speak of 'eternal' or 'absolute' truth. Truth is relative to our historically and culturally conditioned lives (Canale 2007:99).

Scharf (2012:187) underlines that socially constructed concepts of truth and ethical, as well as epistemological relativism, reader-response hermeneutics, narrative forms of theology that oppose propositional truth and the idea that texts create worlds as opposed to describing reality, all tend to shift authority away from the text of Scripture to listeners and the communities they form. He states that the New Homiletic, with its emphasis on the power of narrative and its insistence on helping listeners experience the text, in practice ignores the revelatory significance of other genres and is reluctant to speak with authority or to make concrete ethical demands on listeners (Scharf 2012:188). In our view, however, the absoluteness of theological truth does not depend on the epistemological characteristics of human reason or the changing realities of temporal beings, but on the transcendent content of divine revelation (Canale 2007:100). Viewed from a Reformational viewpoint, the echo of 'What is truth?', as asked by Pontius Pilate, is palpable. Of course, Jesus says: 'I am the way, and the truth' (Jn 14:6, [authors' emphasis]). The idea that Jesus is the truth is considerably different from the cultural notion of truth into which we have been educated. Canale (2007:101) refers to truth as an aspect that describes divine nature. God has manifested himself directly in the flow of human time, showing himself to us as he is, showing what truth is and what truth does. Since God's being, character and purposes do not change (M1 3:6; Heb 6:17-18), his truth is immutable (Ps 132:2; 146:6) in the flux of time (Ps 100:5; 117:2). The words in the Old Testament for 'truth' underline the reliability, firmness and faithfulness of God's truth, that is, its absoluteness and universality through time and cultures (Canale 2007:93).

According to Forke (2016:156), the Christian faith is highly invested in the concept of truth. Jesus came into the world 'full of grace and truth' (Jn 1:14). He characterises his mission in terms of truth: 'I have come into the world to bear witness to the truth' (Jn 18:37). Furthermore, Jesus promises his followers that they will know the truth and that the truth will set them free (Jn 8:32). He begins to reveal the content of this truth when he calls himself 'the way, the truth, and the life' (Jn 14:6). Jesus promises that his followers will enjoy help, because 'when the Spirit of truth comes, he will guide you into all truth' (Jn 16:13). Finally, Jesus directs his followers to the place where they will find the truth when he prays on the night before his death that 'your word is truth' (Jn 17:17; Forke 2016:155).
In Scripture, then, in the flux of human history, truth stands on the ontological basis of God's revelation of his very being by presence (Jn 1:14; 1 Jn 5:6), action (Jn 1:17), words (Jn 17:17; Ps 119:43, 151, 160; Dn 10:21) and teachings (Ps 11 9:142). Canale (2007:102) indicates that God's historical revelation reaches its highest manifestation in Christ who, as God himself, is the truth (Jn 14:6). He reveals truth by his ontological and epistemological presence and action, and by epistemologically putting the truth in words and teachings (Mk 12:1). Jameson (2018:183) indicates that, surrounded by so much false truth, researchers need to make sure that they are dedicated to the truth of God. Craddock (1985:33) states that our task as preachers is not just to tell the truth, but to get the truth heard in order to result in a creative listening to the Word. Although emotional manipulation may be a pitfall, one cannot ignore the fact that persuasive preaching is indeed intentional in its essence and has the purpose to move listeners to find delight in the feelings of the text. Persuasive preaching does not depend on the preacher's feelings and opinions, but on preaching that conveys the rhetorical purpose of the particular passage.

\section{Preaching is neither only cognitive nor only emotional}

Modernity introduced Enlightenment rationalism in the first half of the 18th century. It argued that Christian belief was rational and should be so robust as to withstand rational and critical examination.

Jameson (2018:186) highlights that a series of arguments based on logic and reason to justify and/or refute the existence of a God thus began. He argues that modernist preaching was essentially an intelligent activity that assumed cognitive skills among hearers. The modernist sermon enjoyed a particular line of thought in which judgements and application were made in a coherent and orderly argument. Beville (2010:12) offers the important distinction that it was not essentially intellectual, but inherently rational. In other words, it assumed that reason would be employed to enlighten. Even though people could be moved emotionally by preaching, they were required to understand its content and accept its conclusions first. In the opinion of Beville (2010:12), in those days preaching expounded a text that had syntactical structure and content that could be explicated:

There was, therefore, not just a faith in the truth of the text but a concomitant and coterminous faith in reason itself. Thus preaching engaged only the intellect, only the cognitive side. (p. 13)

The danger of preachers acting as sermonisers rather than preachers therefore underpins our reflection.

Although logical and polished, the sermons of sermonisers were utterly harmless when it came to touching people's lives (Kruger 2019:249). In history, this rational one-sidedness led, on the flipside of the coin, to excessive emphasis on emotion. Piper (1995:49) mentions that the common strategy of preachers for awakening people's emotions and engaging their hearts then was and still is to find the areas of human 
life when emotions are already running high and when hearts are already engaged in rooting the sermon there: pain in marriage, stress at work, the power of sexual temptation, the breakdown of community or the absence of intimacy and vulnerability. The reason preachers do not believe that the greatness of God, the spirit of transcendence, the glory and majesty of Christ - the deep things of the Spirit centre - will move the hearts of our people and awaken profound affections, is that these things do not move people: they do not truly awaken their emotions (Piper 1995:31).

\section{Descriptive analytical perspectives on the new normal of the post-pandemic postmodernist}

Van Huyssteen (2004:88) underlines the important idea that people want to relate with reality through their interpreted experience. The idea of a new normal is often mentioned. In the previous sections, we have tried to indicate that a postmodernist outlook should not only be seen as a phase that has followed modernism. A postmodernist outlook, as an attempt to deconstruct current knowledge systems, is also an attempt of people to make sense of the times they are living in (Potgieter \& Van der Walt 2015:239). Viewed from a homiletical point of view, it is important to realise that, while preaching to listeners, some listeners could possibly have the experience that their worlds are falling apart because of a postmodernist outlook while other listeners are not feeling satisfied with the continuous flux of everything. Listeners' experiences are indeed influenced by what could be called the Zeitgeist. Olthuis (2012:5) takes another approach in highlighting the fact that a postmodernist approach has put reason in its place because of the fact that life is according to this kind of outlook about more than mere logic. One's outlook on life also determines the way listeners will eventually look at life itself (Potgieter \& Van der Walt 2015:243). Concrete experiences in daily life influence what the abovementioned authors have described as someone's life-chart. This is exactly the reasoning behind the current section, namely the COVID-19 pandemic has indeed offered experiences of uncertainty and even fear to listeners a virtual environment. It becomes evident from the abovementioned perspectives that the idea of cognition (trying to make sense of what is happening) is more than a cognitive endeavour.

Gilder (2020:2), for example, underlines the idea that the pandemic has indeed influenced people's ability to think clearly in an environment where logic still prevails. Matters such as social distancing, not meeting each other within the space of a building and love that should be shown in staying away, should be processed by listeners. Listeners in need of unambiguous theological answers about the pandemic and the phenomenon of people who are reflecting on whether this pandemic is part of the sign of the end of times, is a striking example. There is more to this matter, because it is about thinking, but people's feelings and actions could not be separated from the cognitive aspects.
In mentioning the idea of a post-pandemic postmodernist world, awareness that the outbreak of the coronavirus has already influenced people's lives deeply during 2020, is pivotal in our interpretation. But it should also be acknowledged that the threat of the virus is not something of the past and it will still be a reality for years to come (Taylor 2015:7). Even within the context of speaking about a post-pandemic world, manifestation of new variants of this virus will remain a threat to people from all age groups. Whether we are still swimming against the powerful stream of the pandemic or whether we can already speak about a post-pandemic world after vaccines have been made available, will not be examined in this article. It could therefore be more correct to rather speak about the liminal phase of a post-pandemic postmodernist life. Liminality refers to any betwixt and between situation - a situation or place that is on the threshold and is therefore neither here nor there (Wepener 2012:295).

Based on the previous insights, it could be said that preachers have to be prepared to preach to listeners moving towards a post-pandemic postmodernist context. We want to elaborate on the idea that listeners are indeed looking to make sense of what is happening in their world. Preaching could offer dynamic opportunities in this process.

\section{Descriptive-analytical perspectives on the appeal of the sermon that is focussed on thought patterns, emotions and listeners' daily lives}

We assert that the Holy Spirit converts and sanctifies the whole person, not just the mind, heart or needs. The Holy Spirit appeals to the mind and emotions to move the will. There must be a cognitive element in every sermon, because every true sermon must be based on an accurate understanding of some portion of Scripture. Preaching, however, cannot stop there. Beville (2010:7) is convinced that there should also be an affective element, for no truth is revealed merely to be comprehended. God makes a claim upon our lives, and ordinarily one responds to that claim not merely because one comprehends it, but because the heart is stirred by it. Beville (2010:11) continues by stating that, ultimately, it is not the sensuous experience of the preaching or the superior logic of the argument that counts, but the power of the Holy Spirit at work. It includes cognitive communication and an emotional experience, but, primarily, it is a spiritual awakening and quickening of the soul. In other words, preaching is not just rhetoric; it enjoys spiritual resonance that vibrates in the soul. Scott-Wilson (2007:3) even indicates that preaching should invite listeners to meet God in the text. Preaching is consequently bearing witness of a significant event between the text and the listeners. The above-mentioned aspects underline the responsibility of preachers to preach the living voice of God's Word in order for listeners to experience the joy, because their hearts are being delighted or stirred up by the message itself.

There is a real need for pathos (feelings or emotions) in balance with logos as Arthurs (2005:17) argues. He is convinced that preaching which addresses the emotions 
along with the mind is more effective than preaching which speaks only to the mind. This truth seems self-evident; yet pathos receives little attention in homiletics texts (Arthurs 2005:13). In view of this lacuna, it is important to state that it deserves a central place in homiletical theorising and practice - a higher place than it currently occupies. Arthurs (2005:14) indicates that we need not put pathos against logos. Preaching must include a strong cognitive element; else it is not preaching. Without a dominant idea derived from a biblical text and supplemented with other ideas, a sermon is merely sound and fury signifying nothing. No ethical communicator uses pathos to induce an audience to act contrary to reason. That is manipulation, not persuasion. Ethical (and effective) communicators use pathos to prompt people to act in accordance with the truth.

Immink (2019:18) avers that the sermon intends to move the mind, generate thoughts and feelings, appeal, motivate, inspire, and so forth. The question arises: Does the sermon enable listeners to realise what God is doing in their lives? Immink (2019:19) refers to this aspect as the believer's spiritual awareness of God's real presence. Immink (2019:5) underlines that, when communities of faith participate in worship, the idea is that they are doing it in the name of God. Our human awareness of God's presence and being addressed by him, is all wrapped up in psychological, affective, cognitive and spiritual mechanisms and processes.

\section{Descriptive-analytical perspectives on the helping listeners to make sense of what is happening as well as on remembering}

In our visualisation of the methodology discussed here, we want to arrange our research according to the phases identified by Dingemans. The idea of cognition, as well as Paul Ricoeur's viewpoint of the hermeneutic of narration in order to analyse the phenomenon of listeners' participation while listening to sermons, will now be addressed. It is our endeavour to underline the essence of listeners who are emotionally and cognitively involved in the act of preaching, and that preaching should enable listeners that the past persists in the present.

\section{People are trying to make sense of their experiences-role of cognitive maps}

The idea of cognitive maps was mentioned earlier, and this aspect will be looked at more closely within this section. Berg and Theron (2006:106) observe that people are approaching daily life experiences with well-defined cognitive maps. Their cognitive maps are dependent on their concrete experiences. The older these maps are, the more detailed they may possibly be. It is important to realise that cognition is a process by which people try to make sense of life (Fiske 2004:122). The implication of this statement is that people are understanding experiences of daily life based on the familiar and old information (Fiske 2004:143). In their turn, Baron and Byrne (1994:108) highlighted the need to reflect on and expand one's understanding of people and events. When experiencing positive feelings (affect), difficult tasks seem easier to deal with. On the contrary, people tend to cope not so well with tasks and problems when they are experiencing negative feelings (Baron \& Byrne 1994:115). Until now, people have become aware of the effects of the pandemic because of regular admonitions to adhere to social distancing, as well as to stay at home to not be infected. They have already acquired a mental map, namely a representation in which information has been stored and decoded regarding the phenomenon of the COVID-19 pandemic. One could also say that it is a spatial representation of the outside world or reality. Concrete experiences of the COVID-19 pandemic have enabled people to form these mental maps and have caused certain perceptions of the new normal.

Although cognition has primarily to do with people's thinking processes, it could not be separated from listeners' feelings and actions (Louw \& Louw 2007:23; Peterson 2003:29; Woolfolk 2007:39). While highlighting cognition, aspects such as body, people's senses and the importance of one's environment (social cognition) are also taken seriously (Eysenck \& Keane 2010:571-572). It is important to acknowledge that people rely on mental maps to store knowledge of places, experiences and routes in order to engage in their navigation processes. The emphasis on experience within a postmodernist outlook on life has become even more complicated due to the COVID-19 pandemic with its emphasis on both feelings and understanding. It has thrown people into a state of fear and chaos.

Uncertainty about the exact outcomes of this pandemic in all spheres of life is part of the problematic essence related to listeners' mindsets. The philosopher, Marten Heidegger, once emphasised the notion of angst that relates to a feeling or mood (Gefühl) as indication of an encounter with nothing or nothingness (Pembroke 2013:21). In and through the experience of angst, a person, in fact, tends to lose his grip on the world. The COVID-19 pandemic has once again reminded us of how quickly one could lose the grip on life. Preaching as a meaningful act of helping to think about God, must enable listeners in their endeavour to make sense of their fears and uncertainty. This will be elaborated on in the following section.

\section{Paul Ricoeur on the hermeneutic of narration in helping} listeners to remember

Atkins (2004:25) addresses the idea that 'at the heart of all worship lies remembrance'. Arthurs (2017:33) confirms this very idea that preaching could be seen as a communicative act during which preachers are 'stirring up' or inspiriting the listeners' memories. Kandel (2006:16) builds on this idea and reflects on people's memories, which actually enable them, not only to remember important past events, but also to recall the exact emotion or feeling in the present. This is even more relevant when preaching to listeners in a post-pandemic postmodernist world in which feelings and experiences 
stand central. To remember, is to bring certain things from the past into the present, because the identity of Christians is closely related to what is being remembered.

Ricoeur's (1998:300) emphasis on the hermeneutics of narration connects, to our mind, with people's desire to experience the content of what is being proclaimed to them. At the deep level of preachers' responsibility to preach, lies the notion that they are enabling listening participants to actually see the old and the new during the sermon. All listeners do indeed have experiences or memories about God, his salvation in Christ and the meaning or significance of the text in their lives. Consider in this light that Ricoeur (2004:22) draws a distinction between memory (la me'moire) as intention, and memory (le souvenir) as the thing intended. The key in bridging this gap or unlocking this challenge is to help listeners remember things or have memories of the past, which again is reminiscent of Ricoeur's notion of narration. In the communication process, two challenges are faced, namely the difficulty to recall or, one could also say, the struggle against forgetting and the fear of having already forgotten (Ricoeur 2004:31). All memories do fade after all as time goes by resulting in a loss of accuracy pertaining to le souvenir.

Ricoeur is adamant that the ability to remember and to recall, lies on the level of cognition or the attempt to make sense of life, but never without the importance of the colour that experiences offer to what is being remembered (Ricoeur 1998:21). The notion of emotional involvement in remembering past events should be acknowledged. One also must admit that this does not merely embody a singular emotional involvement, but may be related more extensively to different levels of emotional engagement within the act of remembrance, that is, anamnesis (Brancatelli 2015:17). This process will inevitably start with the recollecting of what has happened in the past (the factual basis), but this memory will lead to a unique interpretation of meaning according to this basis of what has been recollected. Therefore, events that are remembered and the significance of these, enjoy interplay in the listening process. The idea of participation within the liturgical framework of listening as well as the emotional engagement with the content of the sermon suppose, according to Gaarden (2014:7), that the outcome of listening is not merely a mental understanding of words, but rather a new understanding (meaning identification) where listeners' own stories could entertain a dialogue with the words of the sermon.

Preachers are therefore called to reminding their listeners of the treasury (familiar and new perspectives) of the gospel. In utilising words, they are, in fact, stirring listeners' memories. The emotional dimension in stirring memories along with the cognitive perspective, which is focussed on understanding, could hardly be underestimated. Memories are inevitably filled with feelings that could be happy or unhappy. This is exactly what Ricoeur, according to Brancatelli (2015:14), describes as the intersecting phase where cognitive and emotional aspects meet each other in order to make meaning. Therefore, different levels of meaning within a passage of the gospel suppose different levels of emotional engagement. Listeners are recalling those experiences of the past and the memory thereof resurfaces, especially through vivid images (Ricoeur 2004:43). Within the framework stated in the research problem of preaching to listeners within a post-pandemic postmodernist context, the challenge for a praxeology will be to draw listeners within a changing context closer to the living God and to the realisation of what he has fulfilled in Christ. In order to be functional to this kind of praxis where living memories are present, a particular narrative is needed (Brancatelli 2015:22).

We are of the opinion that the narration of preaching to recognise the traces of God in the present, needs to take into account that preaching has to assign significance and meaning to past events, in particular, the narrative of the gospel (Hervieu-Léger 2000:11). According to Ricoeur, a hermeneutics of narration functions in accordance with two focal points that interact in an elliptical manner (Brancatelli 2015:57). The cognitive and affective dimensions of the individual's memories as two centres should not be seen in isolation, but with cognisance of the wider traditional, cultural and social context in which listeners are living. Ricoeur (1998:30) visualises the importance of narrative re-enactment as a dynamic process that draws the past into the present and future; ritual activities are important to this process. The basis for this kind of narrative re-enactment is found in the power of memories and remembrances. The praxeology is aimed at this kind of re-enactment or, one could also say, acting or reliving while drawing on the power of remembering an event from the past in such a manner that it influences the present in order to experience a solid foundation for hope.

Based on this research, the stirring of memories through remembrance is aimed shown to be targeted at one's heart, leading into a context in which the dichotomy between mind and emotion can no longer be upheld.

\section{Normative perspectives on truth that finds delight in the feelings of the text according to 2 Samuel 17}

In accordance with the visualisation of the methodological insights of Dingemans, as described at the beginning of this article, the present section will provide perspectives on how preachers should concentrate on the rhetorical movement and feelings in a text in order to guide listeners to experience these. The dichotomy between mind and heart should be avoided, and a further section below will explore this idea.

We find one bright moment in the dark history of David and Absalom, and aim to extract normative perspectives of truth from it. In 2 Samuel 17, one comes across a description of David's critical circumstances as a fugitive 
due to the acts of his son, Absalom. Ahithophel and Husai advised Absalom. Eventually, the advice of Husai was accepted, which provided an opportunity to save David's life (Wiersbe 2006:15). Husai's creative message pesuaded Absalom, as well as those around him listening. Evans (2004:244) pinpoints the main reason for this when he indicates that Husai's message was aimed at being true and persuasive. A closer look at the message shows that he addressed the listeners in the first-person plural, namely 'we'. He fully associates himself with the listeners (Manser 2010:403). Contrary to Husai, Ahithophel utilises the first-person singular, 'I'. A further characteristic of the difference between the two messages is that Ahithophel focusses on mere facts and therefore alienates himself from the listeners. This is an indication of a deep-seated attitude, namely that his message has not really been internalised (Evans 2004:245). Consequently, no one agreed with him. Based on clinical facts, Ahithophel's military strategy is outstanding. Against all logical considerations, Husai's advice is accepted. Wiersbe (2006:17) underlines the following reasons for this:

- Although Husai's speech is much longer than Ahithophel's, Husai pays attention to vivid images and enables his listeners to see the implications of his advice. The listeners could visualise the impact of the message.

- Despite the obvious military shortcomings in Husai's speech, his rhetoric is convincing. Ahithophel's insistence on his own insight and knowledge creates a communicative distortion between ' $\mathrm{I}$ ' and 'you'.

- Strictly speaking, Ahithophel fails in answering Absalom's exact question. The challenge of providing an overview on a possible outcome goes unanswered. Absalom and his men could not see the route they should adhere to.

- On the other hand, Husai achieves exactly this. He utilises metaphors and comparisons from daily life. The following examples (2 Sm 17:5-14) give evidence for this recognition:

- [fierce as a wild bear robbed from her cubs]

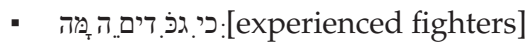

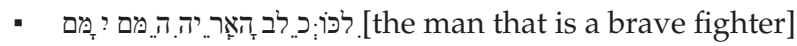

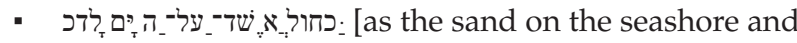
dew settles on the ground]

- It is clear to Absalom and his men that if they do not accept Husai's advice, they would experience severe consequences. Listening is transformed into seeing what they should do.

- Husai's persuasive message is based on the fact that people experience the world in terms of vivid images. Memories of concrete circumstances offer glimpses towards further insight.

See Table 1 for a schematic representation of the difference between the two speeches.
TABLE 1: A schematic representation of the difference between the two speeches.

\begin{tabular}{|c|c|}
\hline Ahithophel's rhetoric & Hushai's rhetoric \\
\hline Listen to my reasons (verse $1-3$ ). & $\begin{array}{l}\text { See and feel the future outcome } \\
(7,10,11-12) .\end{array}$ \\
\hline $\begin{array}{l}\text { Focus of attention is on the speaker, } \\
\text { who refers to himself four times: } \\
\text { verse } 1,2 \text {. }\end{array}$ & $\begin{array}{l}\text { Focus of attention is on the listener: } \\
\text { addresses 'you', 'yours' and 'we' } \\
\text { six times. }\end{array}$ \\
\hline Gives a logical plan. & Envisages the plan. \\
\hline Advice supported by facts. & $\begin{array}{l}\text { Facts supported by metaphors and } \\
\text { pictures and imagination. }\end{array}$ \\
\hline Focussing on the ears. & Focussing on all the senses. \\
\hline Delivering information. & Experiencing information $(11,12)$. \\
\hline Giving out information. & Getting information through. \\
\hline Concepts without images. & Combines concepts with images. \\
\hline Telling. & Showing and experiencing. \\
\hline
\end{tabular}

Note: Compare with: Wiersbe, W.W., 2006, Preaching and teaching with imagination, pp. 41-55, Baker Books, Grand Rapids, Ml.

\section{Conclusion: Feel the feelings of the text}

In delivering a sermon, preachers should help listeners through a hermeneutic process of narration (communication) not merely to hear the spoken words, but to see what the passage offers them. It could also be said differently, namely that the act of preaching puts something poignant in action in listeners' lives, something that is described by Immink (2014:22) as the performance process. A one-sided emphasis on only the cognitive aspects of a message could be insightful, but the persuasive element could be endangered, because the emotional aspect has been ignored. A message in which the cognitive aspects function at the expense of emotional appeal could lead to a praxis in which only one sense, namely hearing is integrated. The sermon should make the relevance of the passage clear to the listeners by adhering to the rhetorical flow of argumentation in the text. Speaking of the truth is an integral aspect in the act of preaching, but it should indeed be connected to daily life and listeners' feelings about their own memories of daily life.

\section{Strategising perspectives on a homiletical praxeology that connects with listeners in a postmodern world}

The following aspects have emerged around a hermeneutical interaction of the phases in this research, namely the importance of creative or imaginative language that is relevant in preaching, the importance of preaching which should enable listeners to make sense of life, and the influence of memories.

\section{Creative or imaginative language that connects with reality (understanding)}

Preaching that touches listeners' hearts and ability to listen, inspired by the preacher's own delight in the preparation of the sermon, might kindle delight in the listeners' hearts, especially when it becomes clear that the sermon has cut through marrow and bone of the preacher. In delivering a sermon, a preacher is therefore voicing or communicating something that has been clarified during 
their own preparation of the sermon. Based on what the preacher has seen, the sermon should invite listeners to come and see. Artists utilise colours and their brushes to create images, but preachers use words to help listeners see how the gospel is challenging them in their lives. Wiersbe's interest (2006:28) in this aspect of preaching, becomes clear when he states that people's minds are, nevertheless, not debating halls, but picture galleries. Changing or reframing perspectives is indeed the inevitable outcome of preaching. Until now the fact that preaching with a focus on remembrance (anamnesis) is imperative has been underlined, mainly because it deals with re-minding listeners about the relevance of the gospel in their daily lives. Now we want to further emphasise that preachers must cultivate a praxis in which appropriate words, images, metaphors and formulations are functional in a purposeful act of connecting the gospel with the reality of living in a post-pandemic postmodernist world.

To preach a well-known passage week in and week out to the same listeners, could be debilitating. Thomas Long (2005:38) aptly indicates that imagination is part and parcel of the initial canonisation process of the gospel, while the preparation of the sermon, as well as active listening to sermons are no less subject to the imaginative process. Why? Because active listening could also be described as an imaginative process in which people's memories (pictures, emotions and experiences) play a distinct role, but one should concomitantly repeat that words actually function as brushes with colour in the mouths of preachers. It is important to realise that creative preaching enables preachers, as well as listeners to intrinsically experience the gospel in a dynamic manner. Vivid remembrance that include past, present and future are pivotal. To preach, entails helping listeners remember God's presence in their lives and the fact that he keeps on remembering about us.

\section{Preaching as the sharing of memories}

In our discussion about Ricoeur's notion of hermeneutic narration, cognisance of the importance of memories that should be narrated or told, emerges as a crucial topic. Ariel (2014:14) postulates an interesting remark in saying that the concept of appropriation is, perhaps surprisingly, also utilised in the visual arts. Appropriation denotes the idea of taking something for one's own use or the process or repurposing it for your own use. The emotive dimension in this concept cannot be denied. This is the reason why artists adapt concepts from different spheres in order to communicate a specific message (Ariel 2014:9). When we utilise this concept within a theological framework, it means that creative words, based on the gospel, are seized to create new meaning for one's own life. This embodies a hermeneutical process in which listeners participate in the act of self-understanding. In order to reach selfunderstanding, listeners depend on understanding through their preachers. Within a Ricoeurian framework, appropriation would then entail that the listeners are in fact actualising the message of the sermon within their own context to which their memories are hermeneutical keys.

\section{Emotional appeal or the feelings of the text}

In this article, preaching to listeners living in post-pandemic postmodernist world was addressed. The importance of listeners' experiences was highlighted, as well as their need to make sense of their experiences. It seems inevitable that preachers must spend more time on biblical texts in order to have certainty about the unique nature of literary forms (Long 2005:89). It is important to determine the content, but also how this has originally been said. Preaching must deal with the rhetorical impact the passage has on listeners' lives. This rhetorical impact that includes the emotional appeal is indicative of how the passage should be preached. Hence, each passage from the Scripture has cognitive aspects that should be understood, but the underlying rhetoric appeal could not be ignored. Kater (2020:99) refers to affections instead of emotions, because people's affections stem from a deeper level than what people think about when they hear the word emotion. This research has highlighted the fact that preaching without pathos (affection or emotion) is definitely and ultimately impossible. A preacher does not have a message, but is rather a messenger thereof. Every communication, every sermon is rhetorical, because it uses some technique to affect the beliefs, actions or emotions of listeners.

However, the most important reason for the argument made here has to do with communication itself. There is no communication without communion. Whoever wants to preach, must have the listeners in his or her heart. Preachers are to open their hearts before opening their mouths. They should have a passion for others in heart and soul. Preaching is about being among the listeners. In a post-pandemic postmodernist world, this statement is even more important. Bohren employs the German word Sehnsucht of which the nuanced meaning and context are difficult to translate (Bohren 1993:158). It involves a very deep longing. Without Sehnsucht, there will never be preaching driven by passion, that is, affectionate preaching. Sehnsucht describes the mystery of love as the mystery of Christ's presence whereby preacher and listeners are brought together. We are convinced, based on our research, that the beauty of rhetorical devices in all literary forms should be used by preachers in order to make their preaching relevent to their listener's experiences in a post-pandemic postmodernist world.

\section{Conclusion}

At the beginning of this article, the functioning of a field of tension was described by stating that a mixture of premodern, modern and postmodern viewpoints is present in the act of preaching. Suddenly the emergence of the COVID-19 pandemic has also offered challenges. The notion of a post-pandemic postmodernist outlook has been mentioned. Preachers often struggle to determine how to preach the truth of the gospel to people who are 
seemingly wired to experience rather than merely sit and listen to sermons. Listeners should be enabled to see things in their lives differently. In listening, remembering and seeing, a powerful framework arises for listeners to understand, feel and do. In the process, it should not be overlooked that the emotional appeal, or what could be called the feelings of the text itself, should be seen as the departing point.

Preaching the gospel amounts to more than a mere stirring up of emotions. In fact, in a post-pandemic postmodernist world where listeners yearn for answers amid afflictions, profound preaching require revaluation of and interest in the feeling of the text itself. Persuasive preaching is intentional in essence, and has the purpose of moving listeners to find delight in the feelings of the text. It has also emerged from our investigation that preaching to post-pandemic postmodernist listeners does not necessarily require a radical new way of communication, but rather requires greater concern for catching the emotional tone of a particular text. We conclude that preaching to listeners in a post-pandemic postmodernist world certainly offers opportunities to preachers to revisit important principles in order for preaching to instruct, delight and persuade.

In this article, the focus was on the power of the gospel and the dynamic of the emotional appeal of the text in communicating to listeners in a post-pandemic postmodernist society. The importance of the gospel has been underlined, but it is also important to provide perspectives on the listeners affected by this pandemic. Hence, in the next article the unique focus of a homiletical praxis with the emphasis on helping listeners to recognise opportunities to care for people amid social distancing will be clarified.

\section{Acknowledgements Competing interests}

The authors have declared that no competing interest exist.

\section{Authors' contributions}

F.P.K. and B.J.d.K. contributed equally to the writing of this article.

\section{Ethical considerations}

This article followed all ethical standards for research without direct contact with human or animal subjects.

\section{Funding information}

This research received no spesific grant from any funding agency in the public, commercial or not-for-profit sectors.

\section{Data availability}

The authors confirm that the data supporting the findings of this study are available within the article.

\section{Disclaimer}

The views and opinions expressed in this article are those of the authors and do not necessarily reflect the official policy or position of any affiliated agency of the authors.

\section{References}

Ariel, E., 2014, Memory and decision processes: The impact of cognitive loads on decision and regret, Wharton Research Scholars, Philadelphia, PA.

Arthurs, J.D., 2005, The place of pathos in preaching, in the art and craft of biblical preaching: A comprehensive resource for today's Communicators, eds. $\mathrm{H}$. Robinson \& C.B. Larson, Zondervan, Grand Rapids, MI.

Arthurs, J.D., 2017, Preaching as remembering, InterVarsity Press, Downers Grove, IL.

Atkins, P., 2004, Memory and liturgy. The place of memory in the composition and practice of liturgy, Ashgate, London.

Baron, R.A. \& Byrne, D., 1994, Social psychology, Allyn \& Bycan, Boston, MA.

Berg, Z. \& Theron, A., 2006, Psychology in the work context, Oxford University Press, Cape Town.

Beville, K.A., 2010, Preaching Christ in a postmodern culture, Cambridge Scholars Publishing, Cambridge.

Bohren, R., 1993, Predigtlehre, Gütersloher Verlaghaus, Gütersloh.

Brancatelli, R., 2015, Reconsidering the role of memory in religious education, Taylor \& Francis, New York, NY.

Canale, F., 2007, 'Absolute theological truth in postmodern times', Andrews University Seminary Studies 45(1), 87-102.

Craddock, F.B., 1985, Preaching, Abingdon Press, Nashville, TN.

De Leede, B. \& Stark, C., 2016, Ontvouwen: Protestantse prediking in de praktijk, Boekencentrum, Soetermeer.

Dingemans, G.D.J., 1991, Als hoorder onder de hoorders, Kok, Kampen.

Evans, L.H., 2004, Hebrews, Macmillan Publishing Co., Washington, DC. (The communicator's commentary).

Eysenck, M.W. \& Keane, M.T., 2010, Cognitive psychology, Psychology Press, New York, NY.

Fiske, S.T., 2004, Social beings: A core motives approach to social psychology, Wiley, Princeton, NJ.

Forke, T, 2016, 'Offending a postmodern world: The prophet speaks the truth', Concordia Theological Quarterly 80(1), 155-164.

Gaarden, M.L., 2014, Listeners as authors in preaching, Aarhuis University Press, Copenhagen.

Gilder, E., 2020, 'Towards a Post-Pandemic Postmodern Society - Is the pandemic a deconstruction of the postmodern society? Postmodern Openings 11(2), 01-11. https://doi.org/10.18662/po/11.2/153

Groothuis, D., 2004, 'Why truth matters most: An apologetic for truth-seeking in postmodern times', Journal of the Evangelical Theological Society 47(3), 441-454.

Hervieu-Léger, D., 2000, Religion as a chain of memory, transl. S. Lee, Rutgers University Press, New Brunswick.

Immink, G., 2014, The touch of the sacred, Eerdmans, Grand Rapids, MI.

Immink, G., 2019, 'Naming God's presence in preaching', HTS Teologiese Studies/ Theological Studies 75(4), a5453. https://doi.org/10.4102/hts.v75i4.5453

Jameson, B., 2018, 'God, post-truth', Theology 121(3), 180-187. https://doi. org/10.1177/0040571X17749145

Kandel, E.R., 2006, In search of memory: The emergence of a new science of mind, Norton, New York, NY.

Kater, M.J., 2020, Heden, Indien U zijn stem hoort, Alphen van den Rijn, Apeldoorn.

Kruger, F.P., 2019, 'What you eat, I eat and what you live on, I live on': The beauty of the functioning of remembrance and the folly of preaching', Stellenbosch Theological Journal 5(1), 235-258. https://doi.org/10.1163/17455316-20180003

Long. T.G., 2005, The witness of preaching, Westminster/John Knox Press, Louisville, KY.

Louw, D. \& Louw, A., 2007, Die ontwikkeling van die kind en die adolossent, ABC Drukkers, Bloemfontein.

Manser, M.H., 2010, The new Matthew Henry commentary, Zondervan, Grand Rapids, MI.

Mueller, W., 2006, Engaging the soul of youth culture: Bridging teen worldviews and Christian truth, IVP, Downers Grove, IL.

Naugle, D.K., 2002, Worldview: The history of a concept, Eerdmans, Grand Rapids, MI.

Olthuis, J.H., 2012, 'A vision of and for love: Towards a Christian post- postmodern worldview', Koers - Bulletin for Christian Scholarship 77(1), Art. \#28, 1-7. https:// doi.org/10.4102/koers.v77i1.28

Oxford Dictionary, 2016, Oxford Word of the Year 2016, Oxford Languages, viewed 1 November 2020, from https://languages.oup.com/word-of-theyear/2016. 
Pembroke, N., 2013, Divine therapeia and the sermon: Theocentric therapeutic preaching, Pickwick, Eugene, $\mathrm{OR}$

Peterson, G.R., 2003, Minding God: Theology and the cognitive sciences, Fortress, Minneapolis, MN.

Pieterse, H.J.C., 2005, 'Die rol van Godskennis in die ontmoetingsgebeure met God in die prediking', In die Skriflig 39(3), 409-422. https://doi.org/10.4102/ids.v39i3.395

Piper, J., 1995, 'Preaching as worship: Meditations on expository exultation', Trinity Journal 16(1), 47-62.

Potgieter, F. \& Van der Walt, J., 2015, 'Postmodern relativism and the challenge to overcome the "value-vacuum", Stellenbosch Theological Journal 1(1), 235-254 https://doi.org/10.17570/stj.2015.v1n1.a12

Rabey, S., 2001, In search of authentic faith: How emerging generations are transforming the church, Waterbrook, Colorado Springs, CO.

Ramey, K., 2010, Expository listening, Kress Biblical Foundations, Woodlands.

Reid, R.S., 2010, Contemporary images of preaching identity, Wipf \&Stock, Eugene Oregon.

Ricoeur, P., 1998, Exegetical and hermeneutical studies, Chicago University Press, Chicago, IL.

Ricoeur, P., 2004, Memory, history, forgetting, transl. K. Blamey \& D. Pellauer, The University of Chicago Press, Chicago, IL/London. https://doi.org/10.7208/ chicago/9780226713465.001.0001
Scharf, G.R., 2012, “Double listening" revisited: Hearing listeners without compromising faithfulness to the Biblical text', Trinity Journal 33(1) 181-197.

Scott-Wilson, P., 2007, Preach the text or preach the Gospel? Toronto School of Theology, Toronto.

Taylor, E., 2015, Reconsidering the role of memory in religious education, Taylor \& Francis, New York, NY.

Toffler, A., 1980, The third wave, Cox \& Wyman, London.

Troeger, T.H., 2012, 'Seeing visions and dreaming dreams: The imaginative power of preaching hope', in C. Vos, L.L. Hogan \& J.H. Cilliers (eds.), Preaching as a language of hope, pp. 73-80, Uitgeverij Boekencentrum, Zoetermeer.

Van Huyssteen, J.W., 2004, Alone in the world? Human uniqueness in science and technology, William B Eerdmans Publishing Company, Grand Rapids, MI.

Wepener, C., 2012, 'Liminality: Recent avatars of this notion in a South African context', Scriptura 110(2), 293-307. https://doi.org/10.7833/110-0-118

Wiersbe, W.W., 2006, Preaching and teaching with imagination, Baker Books, Grand Rapids, MI.

Woolfolk, A., 2007, Educational psychology, Pearson, Boston, MA.

Yang, J.Y., 2007, Communicative preaching. A homiletical study in the light of Hebrews, ThD thesis, Department of Practical Theology, North-West University, Potchefstroom. 